\title{
KAJIAN EKONOMIS PEMELIHARAAN IKAN LELE (Clarias sp.) DENGAN METODE PEMELIHARAAN SISTEM BOSTER DAN SISTEM KONVENSIONAL
}

\section{ECONOMIC STUDY OF MAINTENANCE LELE (Clarias sp.) WITH MAINTENANCE METHODS OF THE BOSTER AND CONVENTIONAL SYSTEM}

\author{
Maria G.E. Kristiany \\ Sekolah Tinggi Perikanan \\ Jl. AUP No. 1 Pasar Minggu, Jakarta Selatan \\ E-mail: eny.kristiany@gmail.com
}

(Diterima: 12 November 2019; Diterima setelah perbaikan: 14 Juni 2020; Disetujui: 14 Juni 2020)

\begin{abstract}
ABSTRAK
Kementerian Kelautan dan Perikanan (KKP) mentargetkan hasil produksi budidaya perikanan mencapai 16.114.250,69 ton pada tahun 2017 dengan ikan lele mencapai 1.125.526 ton pada tahun 2017. Secara umum budidaya yang dilakukan pembudidaya adalah secara konvesional. Tingkat efisiensi pakan merupakan modal terbesar dalam usaha pembesaran lele. Beberapa upaya-upaya yang telah dilakukan oleh pembudidaya ikan lele seperti yang dikembangkan dengan menerapkan sistem lele sehat boster yang memiliki hasil daging lele yang sehat dan bersih. Tujuan penelitian adalah untuk mengetahui kegiatan budidaya ikan lele yang lebih effisien dan layak dari segi ekonomi antara pemeliharaan secara konvensional dengan sistem boster. Hasil pengukuran kualitas air seperti suhu, pH, DO, Nitrat dan nitrit selama pemeliharaan pada kedua perlakuan masih pada kisaran yang layak, demikian juga data SR, FCR dan ADG masih pada kisaran yang baik. Berdasarkan analisa keuangan diperoleh hasil untuk pemeliharaan di sistem boster : BC ratio; 1.57, BEP; 4.758 dan PP; 0,64 sedangkan pemeliharaan sistem konvensional BC ratio; 1.09 BEP; 6.646 dan PP; 2.7. Berdasrakan analisa tersebut dapat disimpulkan bahwa pemeliharan ikan lele dengan sistem boster lebih ekonomis dibandingkan dengan pemeliharaan dengan sistem konvensional.
\end{abstract}

KATA KUNCI: Ekonomis; ikan lele; boster; konvensional

\begin{abstract}
The Ministry of Maritime Affairs and Fisheries (KKP) targets fisheries production to reach 16.114.250,69 tons in 2017 with catfish reaching 1.125 .526 tons in 2017). In general, the cultivation carried out by farmers is conventional. The level of feed efficiency is the largest capital in the business of enlarging catfish. Some of the efforts that have been made by catfish farmers such as those developed by implementing a healthy catfish booster system that has a healthy and clean catfish yield. The aim of this study is to find out more efficient and economical catfish culture between booster systems and the conventional maintenance. From the results of measurements of water quality such as temperature, pH, DO, Nitrate and nitrite during maintenance in both treatments are still in a reasonable range, as well as SR, FCR and ADG data are still in a good range From the financial analysis the results obtained for maintenance in the boster system: $\mathrm{BC}$ ratio; 1.57, BEP; 4,758 and PP; 0.64 while the maintenance of the conventional $\mathrm{BC}$ ratio system; $1.09 \mathrm{BEP}$; 6,646 and PP; 2.7. From the results of this analysis it can be concluded that the maintenance of catfish with a booster system is more economical than the maintenance with conventional systems.
\end{abstract}

KEYWORDS: Economical; catfish; boster; conventional

\section{PENDAHULUAN}

Ikan Lele (Clarias sp.) merupakan ikan yang banyak dibudidayakan di Asia, Afrika, Eropa, dan Amerika. Ikan

\footnotetext{
\# Korespondensi: Sekolah Tinggi Perikanan

E-mail: eny.kristiany@gmail.com
}

lele ini masuk ke Indonesia pada tahun 1985 (Sudarto, 2004). Lele merupakan salah satu komoditas air tawar yang memliliki potensi untuk dikembangkan, dilihat dari peningkatan pertumbuhan budidaya ikan air tawar pada potensi sumberdaya alam yang dimiliki Indonesia. Seperti yang diungkapkan oleh Wijaya et al. (2014), 
bahwa Kementerian Kelautan dan Perikanan (KKP) menetapkan ikan lele sebagai salah satu komoditas air tawar unggulan Indonesia. Sukoco et al. (2016), menyatakan bahwa ikan lele merupakan komoditas air tawar yang memilik Kementerian Kelautan dan Perikanan (KKP) menargetkan hasil produksi budidaya perikanan mencapai 22,46 juta ton pada tahun 2017. Sedangkan menurut Pusat Data Statistik dan Informasi Kementerian Kelautan dan Perikanan tahun 2018, produksi ikan lele mencapai 1.125.526 ton pada tahun 2017 Ditinjau dari perkembangan produksi ikan lele selama pada tahun (2013-2017) menunjukan hasil yang sangat signifikan yaitu $72,47 \%$ dengan kenaikan ratarata setiap tahun $37,49 \%$. Ikan lele mempunyai kandungan gizi yang cukup tinggi antara lain, lemak $4,5 \%$, protein $17,7 \%$, mineral $1,2 \%$, karbohidrat $0,3 \%$, dan energi $113 \mathrm{kal}$. Meningkatnya produksi ikan lele berakibat pada penambahan area lahan budidaya, penggunaan air, dan pakan. Tingkat efisiensi pakan merupakan modal terbesar dalam usaha pembesaran lele Jaja et al. (2013) dan (Nurcahyo et al., 2016). Seiring dengan perkembangan teknologi dan kemajuan ekonomi, maka usaha untuk meningkatkan kesejahteraan masyarakat perlu adanya teknologi dalam budidaya ikan lele dengan padat tebar tinggi yang bisa diterapkan pada lahan sempit dan menghasilkan kualitas lele yang lebih baik. Beberapa upaya-upaya yang telah dilakukan oleh pembudidaya ikan lele seperti dengan menerapkan sistem lele sehat boster yang memiliki hasil daging lele berbeda dengan sistem budidaya pada umumnya.Tujuan dari penelitian ini adalah untuk mengetahui kegiatan budidaya ikan lele yang lebih effisien dan layak dari segi ekonomis antara pemeliharaan secara konvensional dengan sistem boster.

\section{METODE PENELITIAN}

Sistem boster merupakan sistem yang diterapkan dengan menggunakan obat dan suplemen yang diproduksi oleh perusahaan. Sistem ini memiliki 3 kunci pokok budidaya yaitu, bentuk kolam yang dilengkapi drain di bagian tengah, pakan yang dicampur dengan menggunakan suplemen berupa multivitamin, zat imun, dan enzim, serta pengelolaan air dengan perlakuan penambahan antiseptik, probiotik sesuai SOP (Fish Boster Centre, 2013 dalam Nurcahyo et al., 2016).

Bak dengan volume $5,3 \mathrm{~m}^{3}$, dapat menampung ikan dengan jumlah tebar 5.300 ekor dengan ukuran benih yang tebar $8+1.3$ gekor $^{-1}$. Apabila dikalikan dengan jumlah bak yang akan diisi yakni 6 bak maka akan diperoleh hasil panen sebanyak $3.000 \mathrm{~kg}$. Lama pemeliharaan 3 bulan, dengan ukuran tebar $7-9 \mathrm{~cm}$. Wadah yang digunakan pada budidaya lele boster dapat berupa bak beton atau bak fiber. Adapun spesifikasi bak pemeliharaan berupa bak fiber berbentuk tabung dengan dimensi d: 2,6 m, t: 1,2 $\mathrm{m}$ dan berbentuk kerucut di bagian bawahnya dengan dimensi d: 2,6 m dan t: 0,06 $\mathrm{m}$ dengan kemiringan 5Ú. Pembersihan wadah menggunakan bahan Blue dengan dosis $2 \mathrm{mlm}^{-3}$ dan persiapan media dengan pembuatan fermentasi yang terbuat dari dedak bekatul halus dengan dosis $62,5 \mathrm{~g} \mathrm{~m}^{-3}$ kemudian dicampur dengan planktop $(6,25$ $\left.\mathrm{mlm}^{-3}\right)$, Amino liquid $\left(12,5 \mathrm{ml} \mathrm{m}^{-3}\right)$, Aquaenzim $(0,625$ $\left.\mathrm{g} \mathrm{m}^{-3}\right)$ dan air $\left(125 \mathrm{ml} \mathrm{m}^{-3}\right)$. Sebelum benih ditebar media pemeliharaan diberikan Strees Off dan Fish Immunovit, kepadatan benih yang ditebar pada lele sistem boster ini sebanyak \pm 1.000 ekor $\mathrm{m}^{-2}$. Jumlah yang ditebar pada 6 bak pemeliharaan yaitu 30.230 Copperekor. Pemberian pakan dilakukan pada pukul 07.00, 16.00, dan 22.00 WIB dengan presentase pemberian pakan berturut $30 \%, 30 \%$, dan $40 \%$. Pakan dicampur dengan feed adictive berupa, Progol, Premix, Grotop, Stress Off, Fish Immunovit, Introfloxs-25, Amino liquid, dan Vita liquid. Kandungan protein pada pellet yang digunakan yaitu 33\%. Pengelolaan kualitas air meliputi pembuangan endapan dasar kolam dilakukan setiap sebelum pemberian pakan, dan pergantian air 3 minggu sekali. Dan pemberian 2 jenis probiotik Aquaenzym dan Sel multi. saat terjadi $\mathrm{pH}$ dan DO menurun sehingga dilakukan penambahan Boster manstap, dan AerO2. Pada monitoring pertumbuhan, laju pertumbuhan spesifik ikan lele boster sebesar 5,93\%. Penerapan biosecurity berupa, paranet, dinding berkawat dan washtafel.

\section{HASIL DAN BAHASAN}

Tingkat efesiensi pada pengelolaan pakan sangatlah penting, karena $70 \%-80 \%$ biaya produksi budidaya dihabiskan pada pakan. Ikan lele merupakan jenis ikan omnivora atau pemakan segala. Seperti yang kita ketahui bahwa harga per kg ikan lele sangatlah terjangkau apabila dibandingkan dengan komoditas ikan lainnya. Kebiasaan pembudidaya lele konvensional, untuk menekan biaya pakan, maka digunakan pakan alternatif seperti bangkai ayam atau jeroan ayam dapat dijadikan sebagai pengganti pellet. Ketika petani lele menekan biaya pakan dengan menggunakan pakan alternatif ada beberapa pembudaya yang melakukan budidaya dengan sistem bister Konsep penghematan pakan yakni penambahan suplemen berupa multivitamin, zat imun, dan enzim. Ada dua macam suplemen yang pada umumnya diberikan pada lele, yaitu berupa probiotik dan suplemen yang dapat meningkatkan nafsu makan lele. Menurut Hariono \& Puspita (2013), suplemen yang mengandung bakteri (probiotik) dapat memacu tumbuhnya plankton di dalam air sehingga memperkaya pakan alami bagi lele. Sedangkan 
suplemen yang meningkatkan nafsu makan karena di dalamnya terkandung vitamin sehingga akan memicu pertumbuhan lele.

Pakan yang digunakan berupa pellet terapung dengan kandungan protein $33 \%$, lemak $5 \%$, Serat $4 \%$, abu $12 \%$, dan kadar air $10 \%$. kebutuhan protein yang optimal untuk ikan yang dibudidayakan di daerah tropis memiliki kebutuhan protein lebih rendah yaitu 25$30 \%$. Hal ini sesuai dengan pernyataan Kurniawan et al. (2014), ikan lele membutuhkan pakan bernilai protein tinggi yaitu tidak kurangdari $30 \%$. Lebih lanjut Muhammad \& Andriyanto (2013) juga menyatakan bahwa kualitas protein pada makanan ikan tidak hanya ditentukan oleh kandungannya dalam makanan, sumbernya ataupun daya cerna ikan, tetapi ditentukan oleh jumlah dan keseimbangan berbagai asam amino yang dikandungnya. Asam amino merupakan gugus penyusun protein. Menurut Murtidjo (2001), ada tiga jenis asam amino yang mutlak diperlukan ikan yaitu, lisin, methionin, dan triptophan. Asam amino essensial ini diperoleh dari makanan ataupun dari bakteri yang mengandung zat-zat tersebut, karena asam amino tersebut tidak dapat diprosuksi pada tubuh ikan. Pemanfaatan asam amino dalam tubuh ikan akan jauh lebih efektif jika pada tubuh ikan terdapat kandungan vitamin yang cukup. Pada konsep boster ini, selain pada persiapan air media pada masa pemeliharaan diberikan pencampuran pakan dengan pemberian vitamin C (Stress Off) dengan asam amino cair (Amino Liquid) guna meningkatkan daya tahan tubuh. Sebelum pemberian pakan dilakukan pembuangan air dasar kolam dengan volume air berkisar 200-300 liter. Pembuangan air ini betujuan untuk menciptakan lele yang bersih karena kotoran dan sisa pakan tidak teraduk pada saat pemberian pakan yang menyebabkan kotoran tersebut dapat termakan oleh ikan. Presentase pemberian pakan pada malam hari sebanyak $40 \%$, berbeda dengan pemberian pakan pagi dan sore hari yang hanya $30 \%$, hal ini dilatar belakangi oleh sifat nokturnal ikan lele. Ikan lele aktif mencari makan pada malam hari dimana metabolisme terbaik tubuh ikan lele siap menerima makanan pada malam hari. sebaliknya pada siang hari lele cenderung beristirahat untuk menjaga suhu tubuh. Menurut pendapat Hariono \& Puspita (2013) dan Kurniawan et al. (2014), ikan lele memiliki organ olfaktori yang terletak dekat sungut yang berfungsi untuk mengenali mangsa dan memakannya pada malam hari. Pakan buatan yang digunakan berupa pellet terapung. Pemberian pakan harus dilakukan dengan merata. Lele merupakan ikan yang memiliki usus pendek, sehigga makanan yang masuk akan diserap dalam waktu yang singkat, oleh karena itu penambahan enzim pada pakan dapat membantu lele untuk menyerap makanannya semakin besar ukuran ikan maka pertumbuhan ikan akan lebih lambat, sesuai dengan pernyataan Abdullatif (2014) dan Ahmadi et al. (2012) bahwa presentase kebutuhan pakan dipengaruhi oleh ukuran ikan, benih ikan membutuhkan protein lebih tinggi seiring dengan pertumbuhannya.

Berdasarkan Tabel 1 dapat diketahui bahwa nilai FCR yang diperoleh selama pelaksanaan penelitianyaitu 0,7 . Hal ini sesuai dengan pernyataan Nurcahyo et al. (2016), bahwa sistemBoster mampu menurunkan FCR menjadi 0,7, sedangkan untuk konvensional mencapai FCR 1,4. Menurut Abdullatif (2014), nilai maksimal FCR pada budidaya lele adalah 1,3. Muhammad dan Andriyanto (2013), menyatakan FCR pada budidaya ikan lele berkisar 1,1-1,16. Sedangkan menurut Hariono \& Puspita (2013) FCR budidaya lele berkisar antara 0,81. Hal ini terbukti bahwa sistem boster dapat menurunkan nilai konversi pakan pada pemeliharaan ikan lele. Untuk survival rate kegiatan kedua perlakuan masih dalam kondisi baik.

Tabel 1. Data SR, FCR dan ADG Pada Sistem Boster dan Konvensioal Selama Pengamatan

Table 1. SR, FCR and ADG data on Boster and Convention System during observation

\begin{tabular}{cccc}
\hline Produktivitas & Boster & Konvensional & $\begin{array}{c}\text { Optimal } \\
\text { (Nurcahyo et al., 2016) }\end{array}$ \\
\hline SR (\%) & 75 & 80 & $80-90$ \\
FCR & 0,7 & 1,4 & 1,3 \\
ADG (\%) & 3,7 & 3.49 & 3.53 \\
\hline
\end{tabular}

\section{Kualitas Air}

Sebelum benih ditebar media pemeliharaan diberikan Strees Off dan Fish Immunovit, yang bertujuan untuk mengurangi tingkat stress ikan dan untuk meningkatkan daya tahan tubuh karena adanya perubahan lingkungan dan mencegah serangan penyakit. Adanya penguapan air selama pemeliharaan diperlukan penambahan sampai tinggi air normal 
kembali Muhammad \& Andriyanto (2013) dan Effendi (2012). Monitoring kualitas air budidaya merupakan kunci penting pada keberhasilan suatu budidaya. Pengukuran kualitas air lele dilakukan untuk mengetahui kadar kondisi air yang baik pada proses budidaya. Hasil pengukuran kualitas air terlampir pada Tabel 2.

Kisaran hasil pengukuran kualitas air (Tabel 2), apabila dibandingkan dengan kondisi ideal air budidaya untuk lele dengan beberapa sumber bahwa budidaya lele sistem boster masih memiliki kisaran kualitas air yang baik. Namun terjadi penurunan $\mathrm{pH}$ pada beberapa waktu pemeliharaan ketika setelah terjadinya hujan.

\section{Analisa Finansial}

Berdasarkanperhitungansemua aspek keuangan memperlihatkan bahwa pemeliharaan dengan sistem boster mendapatkan hasil yang lebih baik, walaupun dilihat dari sisi kelayakan usaha semua kegiatan masih pada taraf menguntungkan (Tabel 3).

Tabel 2. Perbandingan Hasil Pengukuran Kulaitas Air dengan Nilai Kisaran yang Optimal

Table 2. Comparison of Water Quality Measurement Results with Optimal Range Values

\begin{tabular}{llccc}
\hline No & \multicolumn{1}{c}{ Parameter } & Boster & Konvensional & Kisaran Optimal \\
\hline 1. & Suhu $\left({ }^{\circ} \mathrm{C}\right)$ & $28-30$ & $27-30$ & 25-30 Rachmawati et al. (2015) \\
2. & pH & $6,4-7,6$ & $6.4-7.4$ & $6,5-8$ Rachmawati et al.. (2015) \\
3. & DO $\left(\mathrm{mg} \mathrm{L}^{-1}\right)$ & $3-4$ & $2-4$ & $>3$ Rachmawati et al. (2015) \\
4. & Nitrat $\left(\mathrm{mg} \mathrm{L}^{-1}\right)$ & $0-12,5$ & $0-20$ & $<$ <6 Rachmawati et al. (2015) dan \\
& & & & Sukoco et al. (2016) \\
5. & Nitrit $\left(\mathrm{mg} \mathrm{L}^{-1}\right)$ & $0,3-0,3$ & 0.7 & $>0,1$ Rachmawati et al. (2015) dan \\
& & & & Sukoco et al. (2016) \\
\hline
\end{tabular}

Tabel 3. Hasil Perhitungan Analisa Ekonomi antara Sistem Boster dan Konvensional

Table 3. The Results of Calculation of Economic Analysis between Boster and Conventional Systems

\begin{tabular}{lcc}
\hline \multicolumn{1}{c}{ Nilai } & Sistem Boster & Konvensional \\
\hline Biaya Investasi (Rp) & 49.455 .000 & 46.509 .505 \\
Penyusutan (Rp) & 3.251 .666 & 3.026 .000 \\
Biaya Tetap (Rp) & 63.051 .666 & 50.051 .000 \\
Biaya tidak tetap (Rp) & 74.505 .576 & 67.055 .000 \\
Biaya operasional (Rp) & 139.490 .000 & 119.106 .000 \\
Hasil Panen (kg) & 11.000 & 8.200 \\
Harga jual (Rp) & 20.000 & 20.000 \\
Pendapatan (Rp) & 220.000 .000 & 164.000 .000 \\
Keuntungan (Rp) & 80.510 .000 & 44.894 .000 \\
BC Ratio & 1,57 & 1,37 \\
BEP (kg) & 4.767 & 2.603 \\
PP (th) & 0,59 & 0.97 \\
\hline
\end{tabular}




\section{Analisa Raba/Rugi}

Selisih dari hasil penjualan ikan dengan biaya operasional merupakan keuntungan yang diperoleh (Sumardika, 2013) dan Widodo \& Syukri (2005). Hasil penjualan ikan sistem boster lebih tinggi dibandingkan dengan sistem konvensional, sedangkan keuntungan yang didapatkan pada sistem boster lebih tinggi hasilnya karena hasil panen yang diperoleh lebih tinggi.

\section{Benefit Cost Ratio (B/C ratio)}

B/C Ratio diperoleh berdasarkan hasil penjualan dan biaya operasional. Untuk dikatakan layak jika mempunyai B/C ratio > 1 (Sumardika, 2013) dan Widodo \& Syukri (2005). Pemeliharaan ikan lele sistem boster $\mathrm{B} / \mathrm{C}$ ratio $(1,57)$ lebih tinggi di bandingkan konvensional $(1,37)$.

\section{Break Even Point (BEP)}

BEP dihitung berdasarkan besarnya biaya produksi dengan jumlah ikan yang di produksi. Hal ini dilakukan untuk menghitung jumlah minimum hasil panen ikan yang dihasilkan (Sumardika, 2013) dan Widodo \& Syukri (2005). BEP dipengaruhi oleh biaya biaya tetap, biaya tidak tetap, hasil panen dan dan harga jual/unit, pada sistem boster diperoleh BEP $4.767 \mathrm{~kg}$ lebih tinggi dibandingkan dengan ikan yang dipelihara konvensional BEP $2.603 \mathrm{~kg}$.

\section{Pay Back Periode (PP)}

Analisa PP dilakukan untuk mmengatahui lamanya waktu yang diperlukan untuk mengembalikan biaya investasi yang digunakan berdasarkan keuntungan yang diperoleh (Sumardika, 2013) dan Widodo \& Syukri (2005). Diketahui bahwa ikan yang diperihara pada sistem boster 0,59 th ( 7 bulan 2 hari th) mempunyai besaran PPyang lebih rendah dibandingkan konvensional 0,97 th (11 bulan 19 hari). Pada sistem boster diperoleh keuntungan yang lebih besar dan pengembalian biaya investasi yang lebih cepat.

\section{KESIMPULAN}

Berdasarkan hasil perhitungan analisa laba rugi di peroleh keuntungan yang cukup signifikan. Keutungan lele sistem boster lebih tinggi lebih dari $80 \%$ keuntungan walaupun biaya investasi ada kenaikan $10 \%$ dari pada sistem konvensional. Pemeliharan ikan lele dengan sistem boster lebih ekonomis dibandingkan dengan sistem konvensional, untuk itu dapat disarankan untuk diaplikasi oleh masyarakat.

\section{UCAPAN TERIMA KASIH}

Terima kasih diucapkan kepada Ketua Sekolah Tinggi Perikanan atas sarana dan prasana penelitian dan publikasi.

\section{DAFTAR PUSTAKA}

Ahmadi. H., Iskandar., \& Kurniawati. N. (2012). Pemberian Probiotik dalam Pakan terhadap Pertumbuhan Lele Sagkuriang (Clarias gariepinus) Pada Pendederan II. Jurnal Perikanan dan Kelautan. 3 No. $4: 99-107$

Abdullatif. Z., Maulana. R., Rahmawati. N. R., Maulidza. A., \& Yusuf. A. (2014). Clarias Booster : Aplikasi Artifical Growth Stimulant (AGS) pada Benih Ikan Lele (Clarias sp.) untuk Mempercepat Waktu Panen. Laporan Akhir Program Kreativitas Mahasiswa. Institut Pertanian Bogor

Effendi, H. (2012). Telaah Kualitas Air: Yogyakarta : Kanasius. 249 hal

Hariono., \& Puspita. R. M. (2013). Panduan Praktik Beternak dan Berbisnis Ikan Lele. Yogyakarta : Media Pressindo.

Jaja., Suryani. A., \& Sumantradinata. K. (2013). Usaha Pembesaran dan Pemasaran Ikan Lele serta Strategi Pengembangannya di UD Sumber Rezeki Parung, Jawa Barat. Jurnal IPB Vol. 8 No. 1 :45-56

Kurniawan. A., Sarjito., \& Prayitno. (2014). Pengaruh Pemberian Ekstrak Daun Binahong (Anredera cordifolia) pada Pakan terhadap Kelulushidupan dan Profil Darah Lele Dumbo (Clarias gariepinus) yang Diinfeksi Aeromonas caviae. Journal of Acuaqulture Management and Technology Vol. 3 No. $3: 76-85$

Muhammad. W. N. \& Andriyanto. S. (2013). Manajemen Budidaya Ikan Lele Dumbo (Clarias gariepinus) di Kampung Lele, Kabupaten Boyolali, Jawa tengah. Media Akuakultur Vol. 8 No. 1: 6371

Murtidjo. (2001). Pedoman Meramu Pakan Ikan. Yogyakarta : Kanisius.

Nurcahyo. I. F., Hidayat. Y., Suryanti. V., Handayani. D. S., Lestari. W. W., \& Pramono. E. (2016). Substitusi Ipteks Pembesaran Lele Tebar Padat. Jurnal IKB Vol. 19. No. 10:37-44

Rachmawati. D., Samidjan. I., \& Setyono. H. (2015). Manajemen Kualitas Air Media Budidaya Ikan Lele Sangkuriang (Clarias gariepinus) dengan Teknik Probiotik pada Kolam Terpal di Desa Vokasi Reksosari, Kec. Suruh. Kab. Semarang. Jurnal PENA Akuatika Vol. 12 No. 1: 24-32

Sudarto. G., Teugels. G., \& Pouyaud. (2004). Description of New Clariid Catfish, Clarias pseudonieuhofii, from West Borneo (Siluriformes, Clariidae). Zoological Studies 43 (1): 8-19

Sukoco. F., A. Rahardja. B. S., \& Manan. A. (2016). Pengaruh Pemberian Probiotik Berbeda dalam Sistem Akuaponik terhadap FCR (Feed Convertion Ratio) dan Biomassa Ikan Lele (Clarias sp.). Journal 
of Aquaculture and Fish Health Vol. 6 No. 1 :24-31

Sumardika P. (2013). Kewirausahaan Perikanan. Jakarta: Bina Sumber Daya MIPA.

Wijaya. O., Rahardja. B. S., \& Prayogo. (2014). Pengaruh Padat Tebar Ikan Lele Terhadap Laju Pertumbuhan dan Survival Rate pada Sistem
Akuaponik. Jurnal IImiah Perikanan dan Kelautan Vol. 6 No. 1: $55-58$

Widodo, U., \& Syukri, A. (2005). Manajemen Usaha Perikanan. Jakarta : Departemen Kelautan dan Perikanan 